\title{
"The relationship between perceived organizational support and organizational commitment among academics: the mediating effect of job satisfaction"
}

$\begin{array}{ll} & \text { Mabasa Fumani Donald } \\ \text { AUTHORS } & \text { Ngirande Hlanganipai } \\ & \text { Shambare Richard }\end{array}$

Mabasa Fumani Donald, Ngirande Hlanganipai and Shambare Richard (2016). The relationship between perceived organizational support and organizational ARTICLE INFO commitment among academics: the mediating effect of job satisfaction. Investment Management and Financial Innovations, 13(3-1), 267-273. doi:10.21511/imfi.13(3-1).2016.13

DOI http://dx.doi.org/10.21511/imfi.13(3-1).2016.13

RELEASED ON Friday, 23 September 2016

JOURNAL "Investment Management and Financial Innovations"

FOUNDER LLC "Consulting Publishing Company "Business Perspectives"

NUMBER OF REFERENCES

0
NUMBER OF FIGURES

0

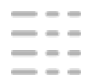

NUMBER OF TABLES

(c) The author(s) 2022. This publication is an open access article. 
Mabasa Fumani Donald (South Africa), Ngirande Hlanganipai (South Africa), Shambare Richard (South Africa)

\title{
The relationship between perceived organizational support and organizational commitment among academics: the mediating effect of job satisfaction
}

\begin{abstract}
This study investigated the relationship between perceived organizational support (POS), job satisfaction (JS) and organizational commitment (OC) in an institution of higher learning. The mediating effect of job satisfaction on the relationship between perceived organizational support and organizational commitment was tested. Self-completion questionnaires were administered to a sample of $(n=302)$ participants. Structural equation modelling techniques were used to test the hypothesized relationships. Results indicate strong significant positive correlations among the variables. Furthermore, findings of the study demonstrate that job satisfaction mediates the relationship between perceived organizational support and organizational commitment. The results also showed that there is a significant relationship between perceived organizational support and job satisfaction. A significant relationship between perceived organizational support and affective commitment, as well as continuance commitment was also noted, but no significant relationship between perceived organizational support and normative commitment was found. Results showed a significant positive relationship between job satisfaction and affective commitment, as well as continuance commitment, but no significant relationship between job satisfaction and normative commitment was found.
\end{abstract}

Keywords: academic staff, perceived organizational support, organizational commitment, job satisfaction, relationships, SEM.

JEL Classification: J28.

\section{Introduction}

The world of work is constantly changing rigorously which results in many organizations facing challenges and also realizing opportunities. Changes arise due to new trends in the global market, political instability, economical changes and technological advancement (Porter, 2000). These continuous changes might result failure or success of the organization. In order to overcome these challenges, organizations have to improve their efficiency or performance by reducing costs, innovating new products and, improving quality and productivity of their original products through providing adequate organizational support. Hakkak and Ghodsi (2013) define perceived organizational support (POS) as a kind of support or cooperation that is required to perform a job successfully. Muse and Stamper (2007) define perceived organizational support as the extent to which employees perceive that their contributions are valued by their organization and that organization cares about their well-being. As such, perceived organizational support becomes one of the significant concepts of improving employees' level of satisfaction and commitment.

(C) Mabasa Fumani Donald, Ngirande Hlanganipai, Shambare Richard, 2016.

Mabasa Fumani Donald, Department of Business Management, University of Limpopo, South Africa.

Ngirande Hlanganipai, Department of Human Resource Management, University of Venda, South Africa.

Shambare Richard, Department of Business Management, University of Venda, South Africa.
It is important to understand that employees' level of satisfaction with their job is one of the keys to the success of an organization. According to Mulinge (2000), job satisfaction as a concept is one of the widely studied in industrial and organizational psychology and in the sociology of work and occupations. Therefore, for that reason, job satisfaction is a complex phenomenon. Job satisfaction is one of the factors that plays central role in the organizations success. Qasim, Cheema and Syed (2012) noted that the employee's job satisfaction is a topic that has acquired significant attention on managers and researchers alike. As such, AkfopureIkhifa, Imide and Okokoyo (2006) claim that job satisfaction has been an important topic over the years.

Kim (2004) concurred that job satisfaction results in organizationally valued outcomes such as productivity, low turnover, and organizational effectiveness. Therefore, this further proves that job satisfaction is one of the important variables that contribute to organization's success. Thus, for an organization to be successful and productive, the employees' concerns and needs should be met (Singh \& Pandey, 2004). Studies show that job satisfaction is a critical issue for research both in Human Resource Management (HRM), organization and management studies, as it is assumed that productivity of a worker hinges on his/her level of job satisfaction (Sattar, Nawaz \& Khan, 2012). As stated by Kreiner and Kinicki (2002), job satisfaction is an emotional, affective response towards various dimensions of employee's job. In other words, job satisfaction is not a unitary concept. 
Organizational commitment plays an important role on success of the organization. Park, Lee and Kabst (2008) examine that employees who exhibit high organizational commitment are the most valuable employees for an organization. According to Meyer and Allen (1991), numerous articles have been written and published on the subject of organizational commitment, but there has been lack of consensus on its definition. Organizational commitment has been extensively and variably defined, measured and investigated, as a result, it has been criticised for lack of precision, giving rise to inconsistent results from various studies (Meyer \& Allen, 1997).

Regardless of the lack of consensus on the different definitions, conceptualizations and measurements, a common theme or subject is shared across all these distinctions, namely that organizational commitment is regarded to be a connection of the individual to the organization (Martin \& Roodt, 2008). Solinger, Van Olffen and Roe (2008) claim that though numerous studies on the construct of organizational commitment have come with a variety of definitions, there is a widespread agreement in the literature that organizational commitment is an attitude. As stated by Meyer and Allen (1991), numerous alternative models of commitment were proposed in the 1980s and early 1990s; multidimensionality was mutual to all. Colakoglu, Culha and Atay (2010) highlighted that there are three components of organizational commitment, namely; affective commitment, normative commitment and continuance commitment.

Many studies have been conducted on the relationship of perceived organizational support either towards organizational commitment or job satisfaction only (Al-Ajmi, 2006; Makanjee, Hartzer \& Uys, 2006; Alijanpour, Dousti \& Khodayari, 2013; Batool \& Ullah, 2013). However, only few have been carried out on the collaboration of these three variables. Besides, there is very little research done on the relationship between perceived organizational commitment and job satisfaction, as well as organizational commitment among academic staff members in the South African context. Lecturers play a very important role in tuning, moulding and refining intellectual ability and capacity of students in high learning institutions during the phase of studenthood. The value and the knowledge that lecturers impart and instil to the students determine a better future for the country.
The academic staff members are a key resource within higher education institutions, having a major role in achieving its objectives. Moreover, the performance of the academic staff members determines much of student learning and success. Therefore, organizational support for the academic staff members is crucial for the quality of higher education institutions. However, very limited information is available on employees' perceived organizational commitment in higher learning institutions.

Universities are the sources of human resource capital and are liable for educating and producing intellects of the nations (Malik, Nawab, Naeem \& Danish, 2010). Therefore, academic staff members are a central element in higher learning institutions with various important responsibilities. As such, the overall performance of the institution is upon their contribution and effort, more importantly upon their level of perceived organizational support and job satisfaction, as well as organizational commitment.

\section{Goal of the study}

This study investigated the mediating effect of job satisfaction on the relationship between perceived organizational support and organizational commitment among academic staff members at a selected South African University. Consequently, the following hypotheses were formulated:

$\mathrm{H}_{1}$ : Perceived organizational support is positively related to employee job satisfaction.

$\mathrm{H}_{2}$ : Perceived organizational support is positively related to employee organizational commitment.

$\mathrm{H}_{3}$ : Employee job satisfaction is positively related to employee organizational commitment.

$\mathrm{H}_{4}$ : There is a relationship between perceived organizational support and the three organizational commitment dimensions (affective commitment, continuance commitment \& normative commitment).

$\mathrm{H}_{5}$ : Employee job satisfaction mediates the relationship between perceived organizational support and organizational commitment.

\section{Method}

2.1. Participants and setting. Three hundred and two (302) academic staff members from a South African higher learning institution participated in this study (males $=59.3 \%$; females $=40.7 \%$; Blacks $=90.4 \%$; Whites $=7.3 \%$; Indian $=1.3 \%$; coloured $=1.0 \%$, age range $36-45$ years). Most participants $(n=285,94.4 \%)$ held post-graduate qualifications (see Table 1 for demographics). 
Table 1. Demographic variables: gender, age, race, highest qualification and tenure

\begin{tabular}{|c|c|c|c|}
\hline Variable(s) & Categories & Frequency (f) & Percentages (\%) \\
\hline Gender & $\begin{array}{c}\text { Male } \\
\text { Female }\end{array}$ & $\begin{array}{l}179 \\
123\end{array}$ & $\begin{array}{l}59.3 \\
40.7\end{array}$ \\
\hline Age & $\begin{array}{c}25 \text { years and } \\
\text { below } \\
26-35 \text { years } \\
36-45 \text { years } \\
46 \text { years and } \\
\text { above }\end{array}$ & $\begin{array}{l}53 \\
88 \\
92 \\
69\end{array}$ & $\begin{array}{l}17.6 \\
29.1 \\
30.5 \\
22.5\end{array}$ \\
\hline Race & $\begin{array}{l}\text { Blacks } \\
\text { Whites } \\
\text { Indian } \\
\text { Coloured }\end{array}$ & $\begin{array}{c}273 \\
22 \\
4 \\
3 \\
\end{array}$ & $\begin{array}{c}90.4 \\
7.3 \\
1.3 \\
1.0 \\
\end{array}$ \\
\hline $\begin{array}{l}\text { Highest } \\
\text { qualification }\end{array}$ & $\begin{array}{c}\text { Degree } \\
\text { Postgraduate } \\
\text { degree }\end{array}$ & $\begin{array}{c}17 \\
285\end{array}$ & $\begin{array}{c}5.6 \\
94.4\end{array}$ \\
\hline Tenure & $\begin{array}{c}\text { Less than } 1 \text { year } \\
1-5 \text { years } \\
6 \text { years and above }\end{array}$ & $\begin{array}{c}56 \\
105 \\
141\end{array}$ & $\begin{array}{l}18.5 \\
34.8 \\
46.7\end{array}$ \\
\hline
\end{tabular}

2.2. Instruments. Questionnaires were used to collect data about the variables under study amongst the academic staff members at a selected South African University. The questionnaire was composed of three instruments which measure perceived organizational support, employee job satisfaction and organizational commitment.

The perceived organizational support questionnaire (POSQ) was used to obtain data about perceived level of organizational support (Eisenberger, Armeli, Rexwinkel, Lynch \& Rhoades, 2001). POSQ consists of 10 questions and also has a five-point Likert scale. An example of an item is "My organization/employer helps me when I have a problem". Ghani and Hussin (2009) reported 0.70 for the perceived organizational support (see Table 2 for reliability indices of scores from the study measures).

Employees' level of job satisfaction was measured by adopting items from the Minnesota Satisfaction Questionnaire (MSQ) (Weiss, Dawis, England \& Lofquist, 1967). The shortened version of MSQ consisting of 20 items was used. The MSQ measures the employees' level of satisfaction with their jobs. An example of an item is "the feeling of accomplishment I get from the job". Martin (2007) obtained Cronbach's Alpha of 0.898 based on 20 items, indicating an acceptable reliability.

The organizational commitment questionnaire (OCQ) (Allen \& Meyer, 1991) was used to obtain data on employee's level of organizational commitment. OCQ consists of 18 items which measure employees' organizational commitment that included affective commitment (6-items), continuance commitment (6-items) and normative commitment (6-items). Examples of items included are "I feel very little loyalty to this organization", "It would take very little change in my present circumstances to cause me to leave this organization", and "I really care about the fate of this organization". Dunham, Grube and Castaneda (1994) reported an Alpha range of 0.74 to 0.84 for affective commitment, 0.67 to 0.78 for normative commitment and 0.73 to 0.81 for continuance commitment. Meyer and Allen (1990) reported an Alpha of 0.87 for affective commitment, 0.79 for normative commitment and 0.75 for continuance commitment. The overall internal reliability of the instrument was 0.931 .

Table 2. Cronbach's Alpha reliable coefficients

\begin{tabular}{|l|c|c|}
\hline \multicolumn{1}{|c|}{$\begin{array}{c}\text { Cronbach's coefficient Alpha } \\
\text { variables }\end{array}$} & Number of items & Alpha \\
\hline $\begin{array}{l}\text { Perceived organizational support } \\
\text { questionnaire }\end{array}$ & 10 & 0.942 \\
\hline $\begin{array}{l}\text { Minnesota satisfaction } \\
\text { questionnaire }\end{array}$ & 20 & 0.916 \\
\hline $\begin{array}{l}\text { Organizational commitment } \\
\text { questionnaire }\end{array}$ & 18 & 0.639 \\
\hline Overall questionnaire & 48 & 0.931 \\
\hline
\end{tabular}

2.3. Procedure. In administering the questionnaire, permission was requested from the university's research office and management to distribute questionnaires to all academic staff members. Consent was also requested from the respondents before distribution of the questionnaires. Questionnaire distribution was done in such a way as to cause no disturbance to work performance of the respondents. The questionnaires were distributed to the respondents during breaks (during lunch time and after hours) and also the respondents were made aware of the time they have to complete the questionnaire. Respondents were given seven working days to complete the questionnaires. After seven days, questionnaires were collected from the respondents for inspection before they were coded.

2.4. Data analysis. A statistical computer package, Statistics Package for Social Sciences (SPSS) version 23 and Stata 13 were used to process the results. Pearson product-moment correlation coefficient was carried out to measure the relationships between the variables, i.e., between perceived organizational support, job satisfaction and organizational commitment.

\section{Results and discussion}

The primary purpose of this study was to determine the mediating effect of employee job satisfaction on the relationship between perceived organizational support and employee organizational commitment. 
Table 3. Descriptive analysis and correlations between perceived organizational support, employee job satisfaction and organizational commitment

\begin{tabular}{|c|l|c|c|c|c|c|c|c|c|}
\hline & \multicolumn{1}{|c|}{ Item } & Mean & SD & 1 & 2 & 3 & 4 & 5 & 6 \\
\hline 1 & $\begin{array}{l}\text { Perceived } \\
\text { organizational } \\
\text { support }\end{array}$ & 3.417 & .993 & & & & & & \\
\hline 2 & $\begin{array}{l}\text { Employee job } \\
\text { satisfaction }\end{array}$ & 3.673 & .663 & $0.661^{* *}$ & & & & & \\
\hline 3 & $\begin{array}{l}\text { Affective } \\
\text { commitment }\end{array}$ & & & $0.527^{* *}$ & $0.556^{* *}$ & & & & \\
\hline 4 & $\begin{array}{l}\text { Continuance } \\
\text { commitment }\end{array}$ & & & $0.519^{* *}$ & $0.512^{* *}$ & & & & \\
\hline 5 & $\begin{array}{l}\text { Normative } \\
\text { commitment }\end{array}$ & & & 0.019 & -0.052 & & & & \\
\hline 6 & $\begin{array}{l}\text { Employee } \\
\text { organizational } \\
\text { commitment }\end{array}$ & 3.360 & .613 & $0.550^{* *}$ & $0.557^{* *}$ & & & & \\
\hline
\end{tabular}

Notes: **.Correlation is significant at the 0.01 level (2-tailed). *.Correlation is significant at the 0.05 level (2-tailed).

Results in Table 3 show that there is a significant positive relationship between perceived organizational support, employee job satisfaction $(r=0.661 ; p<.001)$. This shows that as employees perceive support from their organization, they become more satisfied with their jobs. Therefore, we fail to accept the null hypothesis and conclude that there is a relationship between perceived organizational support and employee job satisfaction. The results also show a positive relationship between perceived organizational support and employee organizational commitment $(\mathrm{r}=0.550 ; \mathrm{p}<.001)$. This also shows that as employees perceive enough support from their employer, they become more commitment to the organization. Therefore, we fail to accept the null hypothesis and conclude that there is a relationship between perceived organizational support and employee job satisfaction.

Similarly, Colakoglu, Culha and Atay (2010) found that perceived organizational support has a significant effect on job satisfaction. Several methodological studies also demonstrated that employees who are supported from their organization are more likely to be satisfied with their job (Tansky \& Cohen, 2001; Riggle, Edmondson \& Hansen, 2009; Ahmad \& Yekta, 2010).

A positive significant relationship was also found between employee job satisfaction and employee organizational commitment $(\mathrm{r}=0.557 ; \mathrm{p}<.001)$. This shows that the more employees are satisfied with their work, the more they are likely to become more committed to their employing organization. Thus, we failed to accept the null hypothesis and conclude that there is a relationship between employee job satisfaction and employee organizational commitment.
The findings are in line with Edwards and Peccei (2010), and Sofdel, Amiri, Masrur, and Hossini (2013) who found a link between employee job satisfaction and employee organizational commitment.

Table 3 also presents a relationship between perceived organizational support and the three organizational commitment dimensions (affective commitment, continuance commitment \& normative commitment). A positive significant relationship between perceived organizational support and affective commitment, as well as continuance commitment $(\mathrm{r}=0.527 ; \mathrm{p}<.001)$ and $(\mathrm{r}=0.519 ; \mathrm{p}<.001)$, respectively.

Therefore, higher affective, as well as continuance organizational commitment is associated with higher perceived organizational support. Results indicate that the employees will feel emotionally attached and connected to the organization, as more organizational support is provided by their employing organization. This is consistent with findings reported by Wann-Yin and Htaik (2011), Bilgin and Demirer (2012). The belief is that employees who are cared for and valued by their organizations will attach to their organization in an affective way (see Table 3).

Results show no relationship found between perceived organizational support and normative commitment $(r=0.019 ; p>001)$. This means that regardless whether organizations provide support or not, it does not affect the level of employee's normative commitment. In other words, organizational support does have effect on employee's obligated feelings to stay with the organization. Contrary, in their study among hotel industry workers, Colakoglu, Culha and Atay (2010) found that there is a positive relationship between perceived organizational support and normative commitment.

3.1. Tests of mediating effects. To test the hypothesised mediated relationship, the two-step mediation process using Structural Equation Modelling (SEM) proposed by Hair, Black, Babin and Anderson (2010) was utilised. The decision to apply mediation analysis to test the conceptual model was influenced by three factors. First, since mediating variables control the relationship between independent and dependent variables and, as such, allow for detailed introspection of results (Baron \& Kenny, 1986; MacKinnon, Fairchild \& Fritz, 2007), the inclusion of mediators in conceptual models provides better explanation of relationships between dependent and independent variables (Berger, 2009; Meuter, Bitner, Ostrom \& Brown, 2005). Second, mediation analysis in social science (survey-based) research is an efficient mechanism to test theories. Third, there is a growing school of thought indicating that "hypothesizing direct 
effects is redundant and obvious, it is fraught with misinterpretation" (Berger, 2009, p. 488). Following Hair et al's (2010) advice, the first of the two-step mediation analysis involved testing the significance of both the direct effects (POS $\rightarrow$ $\mathrm{OC})$ and indirect (i.e., mediated) effects (POS $\rightarrow$ JS $\rightarrow$ OC) (see Figure 1). To this end, path analysis techniques of SEM were employed.

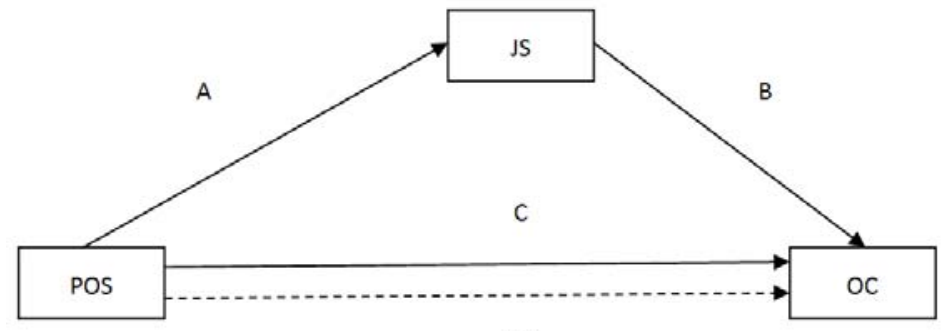

$C^{\prime \prime}$

Direct effect Indirect effect

Fig. 1. Mediation analysis steps

Figure 1 illustrates four path coefficients (A, B, C, and $C^{\prime}$ '), which constitute the elements for testing mediation. Paths A and B represent POS $\rightarrow$ JS and JS $\rightarrow$ OC, respectively. Path $\mathrm{C}$ depicts the direct effect between POS and OC when paths A and $\mathrm{B}$ - including the mediator - are included in the model. Finally, path $C^{\prime}$ is the direct effect POS $\rightarrow$ OC. Step 1 involved assessing the significance of paths A, B, and C'. All these three paths were observed to be significant $\left(\beta_{\mathrm{A}}=.66 ; \mathrm{p}\right.$ $<.001 ; \beta_{\mathrm{B}}=.53 ; \mathrm{p}<.001 ; \beta_{\mathrm{C}}=.72 ; \mathrm{p}<.001 \mathrm{Ap}<$ $.001)$. Thereby, these results provided support for $\mathrm{H} 1$ and $\mathrm{H} 3$.

In Step 2, the direct model POS $\rightarrow$ OC was estimated. The resultant standardized path coefficient of C' was noted to be $(\beta=.72 ; \mathrm{p}<$ .001 ), which invariably suggested that $\mathrm{H} 2$ should be accepted. Thereafter, a combined model that included paths $\mathrm{A}, \mathrm{B}$, and $\mathrm{C}$ was estimated. As usual in SEM, the model diagnostics were considered by assessing several goodness of fit indices before any conclusions pertaining to the model could be made (Hair et al., 2010). These included the model's chi-square $\left(\chi^{2}\right)$, the model's degree of freedom (df), comparative fit index (CFI), the Tucker-Lewis index (TLI), the root mean square error of approximation (RMSEA), the standardised root mean residual (SRMR) and the coefficient of determination (CD). To measure good model fit, the acceptable thresholds of these indices, according to Hair et al. (2010), is $\chi^{2} / \mathrm{df}<3$, CFI $>.9$, RMSEA $<.5$, and SRMR $<.08$. Therefore, researchers first assessed the model fit of the model (Figure 2). Table 4 summarizes these key diagnostics and indicates that there was enough support that the model fit the data.

Table 4. Goodness of fit indices of the mediation model

\begin{tabular}{|l|c|}
\hline \multicolumn{1}{c}{ Fit Index } & Value \\
\hline$X^{2}$ & 8.935 \\
\hline $\mathrm{df}$ & 3 \\
\hline $\mathrm{X}^{2} \mathrm{df}$ & 2.978 \\
\hline $\mathrm{CFI}$ & .992 \\
\hline TLI & .975 \\
\hline RMSEA & .081 \\
\hline SRMR & .014 \\
\hline CD & .547 \\
\hline
\end{tabular}

From Figure 2, it is clear that there was a decrease in the path coefficients from $C^{\prime}(.72)$ to $C(.37)$ and that both coefficients were significant $(\mathrm{p}<.001)$.

Table 5. Mediation analysis results: standardized path coefficients

\begin{tabular}{|c|c|c|}
\hline Path & Direct effects & Mediated effects \\
\hline A & Not tested & $.66^{\star}$ \\
\hline B & Not tested & $.53^{\star}$ \\
\hline C & Not tested & $.37^{\star}$ \\
\hline C' & $.72^{\star}$ & Not tested \\
\hline
\end{tabular}

Notes: ${ }^{*} \mathrm{p}<.001$.

With that it was concluded that job satisfaction partially mediates the relationship between perceived organizational support and organizational commitment. Hence, there is sufficient evidence to accept $\mathrm{H} 4$. 


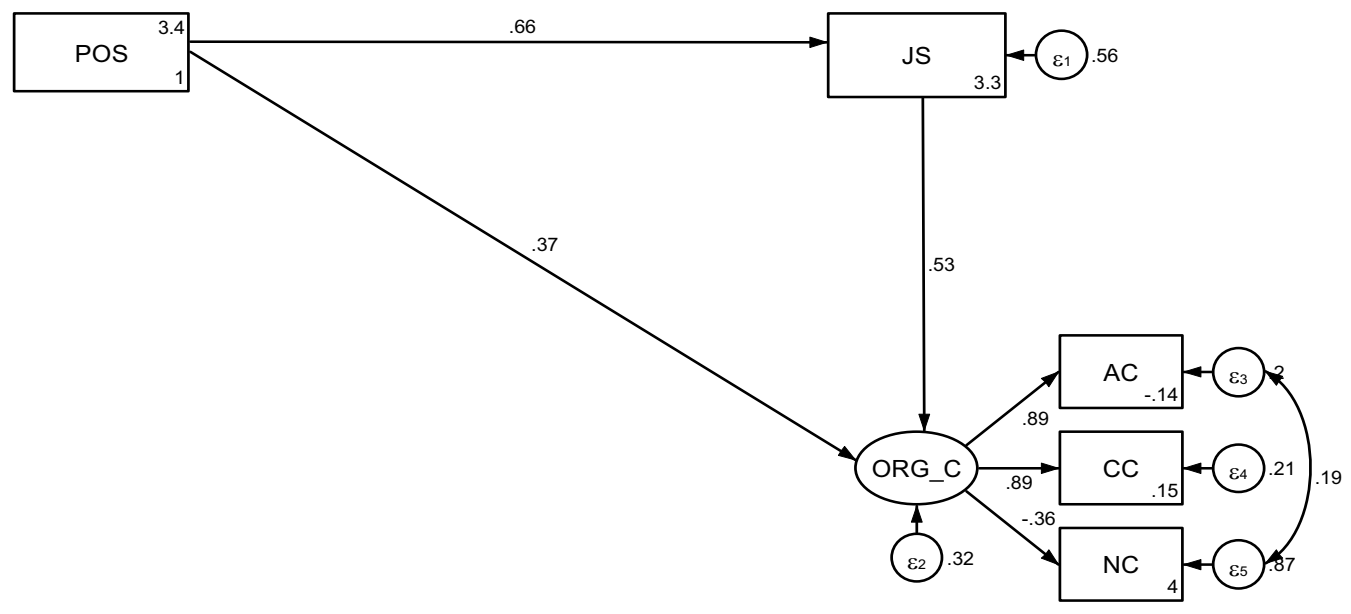

Fig. 2. Mediated relationship: POS-JS-OC

\section{Conclusion}

Findings of this study suggest that there is a relationship between perceived organizational support, job satisfaction and affective commitment, as well as continuance commitment. The findings of the study also suggest that there is no relationship between perceived organizational support and normative commitment, as well as the relationship between job satisfaction and normative commitment. However, findings are constrained by the fact that the data were self-reported, and only derived from academic staff members. Females may have unique organization support needs from males that management may need to be sensitive to.

\section{References}

1. Ahmad, Z.A. \& Yekta, Z.A. (2010). Relationship between perceived organizational support, leadership behavior, and job satisfaction: An empirical study in Iran, Intangible Capital, 6 (2), pp. 162-184.

2. Akfopure, R.R., Ikhifa, O.G., Imide, O.I. \& Okokoyo, I.E. (2006). Job satisfaction among educators in colleges of education in Southern Nigeria, Journal of Applied Sciences, 6(5), pp. 1094-1098.

3. Al-Ajmi, R. (2006). The Effect of Gender on Job Satisfaction and Organizational Commitment in Kuwait, International Journal of Management, 23 (4), pp. 838-849.

4. Alijanpour, M., Dousti, M. \& Khodayari, A. (2013). The relationship between the perceived organizational support and organizational commitment in staff, European Journal of Experimental Biology, 3(5), pp. 165-171.

5. Allen, N.J. \& Meyer, J.P. (1990). The measurement and antecedents of affective, continuance and normative commitment to the organization, Journal of Occupational Psychology, 6(3), pp. 1-18.

6. Baron, R.M. \& Kenny, D.A. (1986). The Moderator-Mediator Variable Distinction in Social Psychological Research: Conceptual, Strategic, and Statistical Considerations, Journal of Personality and Social Psychology, 51(6), pp. 1173-1182.

7. Batool, M. \& Ullah, R. (2013). Impact of Job Satisfaction on Organizational Commitment in Banking Sector: Study of Commercial Banks in District Peshawar, International Review of Basic and Applied Sciences, 1(2), pp. 12-24.

8. Bilgin, N. \& Demirer, H. (2012). The examination of the relationship among organizational support, affective commitment and job satisfaction of hotel employees, Procedia-Social and Behavioral Sciences, 51, pp. 470-473.

9. Berger, S. (2009). Self-service technology for sales purposes in branch banking: The impact of personality and relationship on customer adoption, International Journal of Bank Marketing, 27(7), pp. 488-505.

10. Colakoglu, U., Culha, O. \& Atay, H. (2010). The effects of perceived organizational support on employees' affective outcomes: Evidence from the hotel industry, Tourism and Hospitality Management, 16 (2), pp. 125-150.

11. Dunham, R.B., Grube, J. A. \& Castaneda, M.B. (1994). Organizational commitment: The utility of an integrative definition, Journal of Applied psychology, 79(3), p. 370.

12. Edwards, Martin R., and Riccardo Peccei. (2010). Perceived organizational support, organizational identification, and employee outcomes, Journal of Personnel Psychology.

13. Eisenberger, R., Armeli, S., Rexwinkel, B., Lynch, P.D., \& Rhoades, L. (2001). Reciprocation of perceived organizational support, Journal of applied psychology, 86(1), p. 42.

14. Eisenberger, R., Huntington, R., Hutchison, S. \& Sowa, D. (1986). Perceived organizational support, Journal of applied Psychology, 71, pp. 500-507.

15. Hair, J.F., Black, W.C., Babin, B.J. \& Anderson, R. E. (2010). Multivariate Data Analysis: A Global Perspective, 7th Edition. Upper-Saddle River: Pearson.

16. Hakkak, M. \& Ghodsi, M. (2013). Investigating the Relation between Job Satisfaction, Perceived Organizational Support and Organizational Commitment, International Journal of Management and Humanity Sciences, 2(6), pp. 513-520. 
17. Kim, S. (2004). Factors affection state government information technology employee turnover intentions, American Review of Public Administration, 35, pp. 137-156.

18. Kreitner, R. \& Kinicki, A. (2001). Organizational Behaviour (5th edition). Irwin/McGraw-Hill, New York.

19. MacKinnon, D.P., Fairchild, A.J. \& Fritz, M.S. (2007). Mediation analysis, Annual Review of Psychology, (58), pp. 593-614.

20. Makanjee, C.R., Hartzer, Y.F. \& Uys, I.L. (2006). The effect of perceived organizational support on organizational commitment of diagnostic imaging radiographers, Radiography, 12(2), pp. 118-126.

21. Malik, M.E., Nawab, S., Naeem, B. \& Danish, R.Q. (2010). Job Satisfaction and Organizational Commitment of University teachers in public sector of Pakistan, International Journal of Business and Management, 5(6), pp. 17-26.

22. Martin, A. \& Roodt, G. (2008). Perceptions of organizational commitment, job satisfaction and turnover intentions in a post-merger South African tertiary institution, South African Journal of Industrial Psychology, 34(1), pp. 23-31.

23. Meuter, M.L., Bitner, M.J., Ostrom, A.L. \& Brown, S.W. (2005). Choosing among alternative service delivery modes: an investigation of customer trial of self-service, Journal of Marketing, 69 (4), pp. 61-83.

24. Meyer, J.P. \& Allen, N.J. (1991). A three-component conceptualization of organizational commitment, Human resource management review, 1(1), pp. 61-89.

25. Meyer, J.P. \& Allen, N.J. (1997). Commitment in the workplace. Thousand Oaks, CA: Sage.

26. Mulinge, M.M. (2000). Toward an explanation of cross-sector differences in job satisfaction and organizational attachment among agricultural technicians in Kenya, African Sociological Review/Revue Africaine de Sociologie, 4(1), pp. 54-73.

27. Muse, L.A. \& Stamper, C.L. (2007). Perceived organizational support: Evidence for a mediated association with work performance, Journal of Managerial Issues, pp. 517-535.

28. Park, Y K., Lee, C.I. \& Kabst, R. (2008). Human needs as predictors for organizational commitment and job involvement: An exploratory empirical study, Management Revue, pp. 229-246.

29. Porter, M.E. (2000). Location, competition, and economic development: Local clusters in a global economy, Economic development quarterly, 14(1), pp. 15-34.

30. Qasim, S., Cheema, F.-E.-A. \& Syed, N.A. (2012). Exploring factors affecting employees' Job satisfaction at work, Journal of Management and Social Sciences, 8 (1), pp. 31-39.

31. Riggle, R.J., Edmondson, D.R. \& Hansen, J.D. (2009). A meta-analysis of the relationship between perceived organizational support and job outcomes: 20 years of research, Journal of Business Research, 62(10), pp. 1027-1030.

32. Rocha, C. (2008). Organizational effectiveness of athletic departments and coaches'extra role behaviour, NASSM, pp. 321-323.

33. Sattar, A., Nawaz, A. \& Khan, S. (2012). The contextual impacts on job satisfaction of employees in the developing states like Pakistan, Universal Journal of Education and General Studies, 1(2), pp. 072-083.

34. Singh, Y. \& Pandey, M. (2004). Principles of Organizational Behavior AITBS. Publishers and Distributors (Regd) J - 5/6 Krishan Nagar Delhi-110051 India.

35. Sofdel, H.S., Amiri, M., Masrur, F.F. \& Hossini, R.N.S (2013). Relationship between perceived organizational support, job satisfaction and organizational commitment of sports departments' staff, International Journal of Sport Studies, 3 (12), pp. 1302-1306.

36. Solinger, O.N., Van Olffen, W. \& Roe, R.A. (2008). Beyond the three-component model of organizational commitment, Journal of applied psychology, 93(1), p. 70.

37. Tansky, J.W. \& Cohen, D.J. (2001). The relationship between organizational support, employee development, and organizational commitment: An empirical study, Human Resource Development Quarterly, 12(3), pp. 285-300.

38. Wann-Yih, W. \& Htaik, S. (2011). The impacts of Perceived Organizational Support, job satisfaction, and Organizational Commitment on job performance in hotel industry, The 11th International DSI and the 16th APDSI Joint Meeting, Taipei, Taiwan, July 12.

39. Weiss, D.J., Dawis, R.V., England, G.W. \& Lofquist, L.H. (1967). Manual for the Minnesota Satisfaction Questionnaire. Vol. 22. Minnesota Studies in Vocational Rehabilitation, Minneapolis: University of Minnesota, Industrial Relations Centre. 